\title{
DIAGNOSTIC DIFFICULTIES IN MILD HAEMOPHILIA AND CHRISTMAS DISEASE
}

\author{
BY \\ BARBARA M. FESSEY, M. J. MEYNELL, AND W. T. COOKE \\ From the General Hospital, Birmingham
}

(RECEIVED FOR PUBLICATION JULY 23, 1960)

\begin{abstract}
Two cases of haemorrhagic diathesis are described, where the laboratory diagnosis was confused owing to previous blood transfusions.

Without the help of investigating the relatives, the nephew of Case 1, the haemophiliac, and the uncle of Case 2, with Christmas disease, there would have been considerable delay in reaching the diagnosis and so instituting the correct treatment.
\end{abstract}

Ordinarily the laboratory diagnosis of classical haemophilia (haemophilia A) and Christmas disease (haemophilia B, plasma thromboplastin component deficiency) is easy using the thromboplastin generation test as described by Biggs and Douglas (1953). Nevertheless difficulty arises when the patient mildly deficient in anti-haemophilic globulin or Christmas factor is transfused following haemorrhage.

The concentration of the deficient factor may be raised for a variable period above $30 \%$ with fresh whole blood or plasma, a level capable of producing a normal result with the thromboplastin generation test. The length of this interval is dependent on a number of factors which include the initial anti-haemophilic globulin level of the patient (between 5 and $25 \%$ in the mildly affected), the anti-haemophilic globulin content of transfused blood or plasma, the half-life of anti-haemophilic globulin (eight to ten hours), and the increased rate of utilization associated with haemorrhage. These comments are even more applicable in mild Christmas disease since the clotting factor is more stable and may last in the circulation for several days.

In hospital practice this difficulty in distinguishing abnormalities of mild degree causes therapeutic problems. To clarify the diagnosis repeated quantitative assays would be of value, but all methods are time consuming, some require special reagents, and others a constant source of the same plasma as a reference standard. Also the time necessary for the degradation of transfused anti-haemophilic globulin or Christmas factor will delay correct treatment; often it is not possible to postpone transfusion in order to permit the laboratory to make the correct diagnosis.
Although Hicks and Pitney's screening test (1957) is said to be more sensitive than the standard thromboplastin generation test, it does not differentiate between haemophilia and Christmas disease. It is now accepted that the degree of deficiency of the clotting factor in haemophilia and in Christmas disease is the same in the affected members of a family, i.e., if there is $5 \%$ or less anti-haemophilic globulin all will have the same concentration and be severe haemophiliacs. In between 5 and $25 \%$ the condition is considered mild and all affected members have mild haemophilia. Classical haemophilia and Christmas disease are inherited as sex-linked Mendelian recessives. With a carrier mother the daughters have a $50 \%$ chance of being carriers, and the sons the same chance of being bleeders. With a haemophiliac father all daughters will be carriers and the sons normal, i.e., neither carriers nor sufferers. With this in mind the relevant members of a family may be investigated by a planned approach.

The purpose of this short paper is to demonstrate the value of investigating the relatives of such patients.

\section{Case Reports}

Case 1.-Mr. G. C., aged 64, a blacksmith, was admitted to another hospital on October 31, 1955. complaining of two attacks of painless haematuria, one 18 months and the other nine days before admission. He had been in fairly good health and gave no history of excessive bleeding.

Examination revealed an enlarged prostate; biochemical investigations proved satisfactory and a prostatectomy was performed. Eleven days after, on November 21, the suprapubic wound was found to be leaking urine and the bladder was distended with large 
blood clots. These were removed, but the condition recurred a week later. The patient had been given 4 pints of blood during the first operation and a further 6 pints during the following 20 days.

$\mathrm{He}$ was admitted to the General Hospital, Birmingham, on November 30, 1955, for further invest:gations after having a total of 10 pints of blood, 2 of these on the day before admission. On close questioning, he admitted that he bled excessively following dental extractions, and that his nephew (a sister's son) was similarly affected. Haematological investigations on admission had revealed no abnormality, when the haemoglobin was $81 \%(12.0 \mathrm{~g} . \%)$, red blood cells $3,980,000$ per c.mm., white blood cells 5,600 (normal differential), platelets 370,000 per c.mm., Hess's test negative, bleeding time (Ivy's method) $1 \frac{1}{2}$ minutes, clotting time $\left(37^{\circ} \mathrm{C}\right.$., Lee and White) $8 \frac{1}{2}$ minutes, prothrombin level (Quick's one-stage method) $100 \%$, clot retraction normal. The thromboplastin generation test gave a normal result (Table I).

TABLE I

FIRST THROMBOPLASTIN GENERATION TEST ON CASE 1

\begin{tabular}{|c|c|c|c|c|c|c|}
\hline \multirow{2}{*}{ Reagents } & \multicolumn{6}{|c|}{ Incubation Time (min.) } \\
\hline & 1 & 2 & 3 & 4 & 5 & 6 \\
\hline $\begin{array}{l}\text { Using normal platelets } \\
\text { (1) Normal serum and normal } \\
\text { adsorbed plasma }\end{array}$ & 86 & 53 & 14 & 13 & 13 & 13 \\
\hline $\begin{array}{l}\text { (2) Patient's serum and patient's } \\
\text { adsorted plasma }\end{array}$ & 75 & 37 & 14 & 13 & 13 & 13 \\
\hline $\begin{array}{l}\text { (3) Normal serum and patient's } \\
\text { adsorbed plasma }\end{array}$ & 84 & 50 & 16 & 15 & 14 & 14 \\
\hline $\begin{array}{l}\text { (4) Patient's serum and normal } \\
\text { adsorbed plasma }\end{array}$ & 70 & 16 & 12 & 13 & 12 & 13 \\
\hline $\begin{array}{l}\text { Using patient's platelets } \\
\text { Normal serum and normal } \\
\text { adsorbed plasma .. }\end{array}$ & 62 & 34 & 15 & 13 & 13 & 12 \\
\hline
\end{tabular}

Two days later the haemoglobin fell to $68 \%(10.1$ g. \%). The suprapubic wound was still leaking, so the bladder was reopened and again found to be distended with clotted blood; no bleeding point was discovered. Continuous irrigation of the bladder was begun and 3 pints of stored blood transfused. Four days later a further 3 pints were given and on the following day all bleeding ceased only to restart after

TABLE II

\section{SECOND THROMBOPLASTIN GENERATION TEST ON}

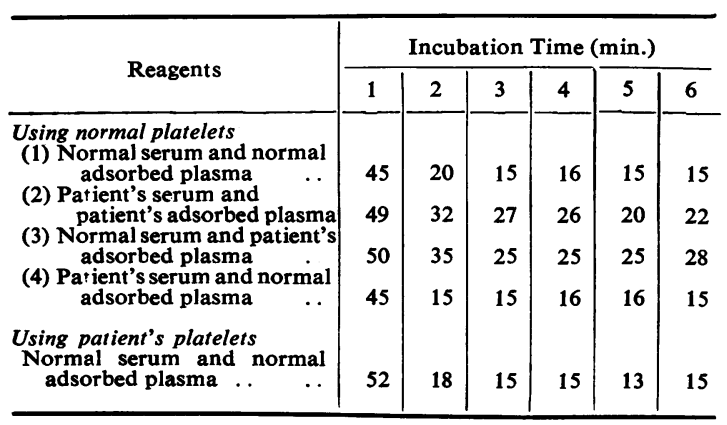

an interval of three days. A repeat thromboplastin generation test taken five days following the last blood: transfusion showed a definite pattern of mild haemo $\vec{F}$ philia (Table II). Unfortunately before this abnormaf result could be confirmed, the patient's genera? condition deteriorated rapidly and a cystoscopy was. performed. Blood was seen coming from the right ureteric orifice and a right-sided nephrectomy wa carried out. After this, bleeding occurred into they nephrectomy wound and was controlled by the applios cation of fresh pork fat. He was given a furthe $\vec{P}$ transfusion of 4 pints of blood and improved-Macroscopic examination of the kidney revealed n\& bleeding point ; sections showed a moderate degree of pyelonephritis.

On December 20 investigations of the patient's nephew (A. F.), who had previously refused to combs to hospital, showed that he bruised easily, bled exces $\rightarrow$ sively after dental extractions, and had had haemoror rhage into the joints as a child. The result of the thromboplastin generation test showed that he was mild haemophiliac (Table III). The third thrombo

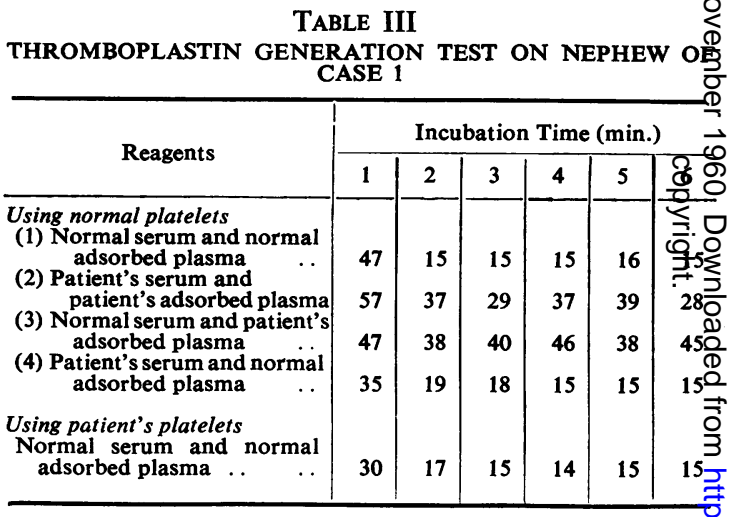

plastin generation test on the patient, seven days after his last transfusion, then confirmed the anti-haemo philic globulin deficiency (Table IV).

The patient was then treated as a case of haemophilia with transfusions of fresh blood an£ plasma. No concentrated anti-haemophilic globulik

\section{TABLE IV}

THIRD THROMBOPLASTIN GENERATION TEST ON CASE

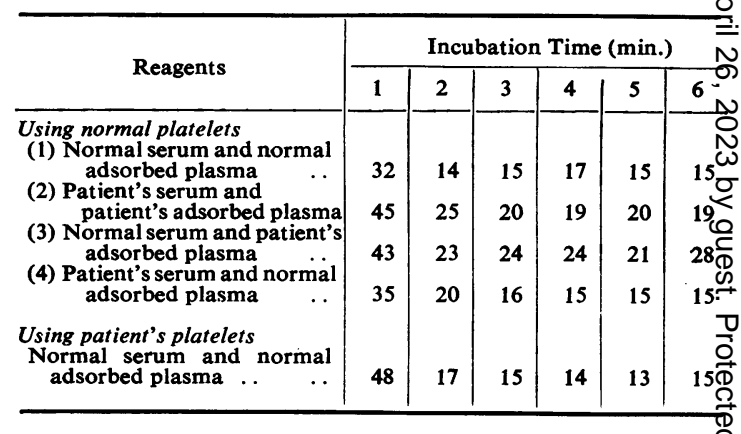


of human or animal origin was available at that time. Despite antibiotic treatment, he developed bronchopneumonia and died on January 9, 1956. At necropsy the remaining kidney showed pyelonephritis.

Case 2.-Mr. G. P., aged 26, a storekeeper, was admitted to another hospital on October 26, 1959, after a haematemesis. Because of a history of a tendency to bleed easily he was transferred to the General Hospital, Birmingham, three days later for further investigation after the transfusion of 9 pints of blood. He had always bruised readily and bled excessively after dental extractions. At 12 years of age he was transfused with 4 pints of blood following the extraction of one tooth. He had had a haematemesis and melaena three years before for which no treatment was given. He had a married sister with no children and one unmarried brother, who were quite normal. However, an uncle, his mother's brother, was said to bleed excessively. Laboratory investigations of the patient showed that the haemoglobin was $71 \%(10.6 \mathrm{~g} . \%)$, white blood cells 7,400 per c.mm., platelets 104,000 per c.mm.; Hess's test, prothrombin level, and clot retraction were normal. The bleeding time was three minutes at $37^{\circ} \mathrm{C}$. (Lee and White's method). A thromboplastin generation test was indecisive (Table $V$ ) and the

\section{TABLE V}

THROMBOPLASTIN GENERATION TEST ON CASE 2

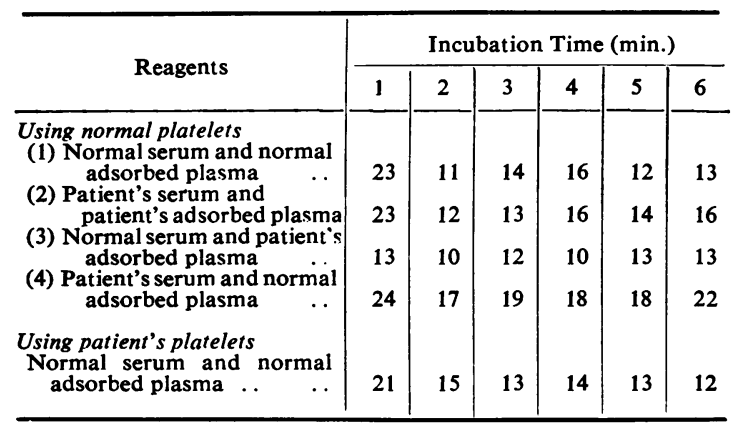

repeat gave a similar abnormal but non-diagnostic result. It was thought that he had mild Christmas disease, and that the thromboplastin generation test did not give a typical pattern because of the previous blood transfusion.

Investigations of his uncle, aged 60, showed that he too had bled excessively following dental extrac- tions, usually necessitating plugging. Haematological investigations were quite negative, but a thromboplastin generation test revealed the presence of mild Christmas disease (Table VI). It was assumed that

TABLE VI

THROMBOPLASTIN GENERATION TEST ON UNCLE OF CASE 2

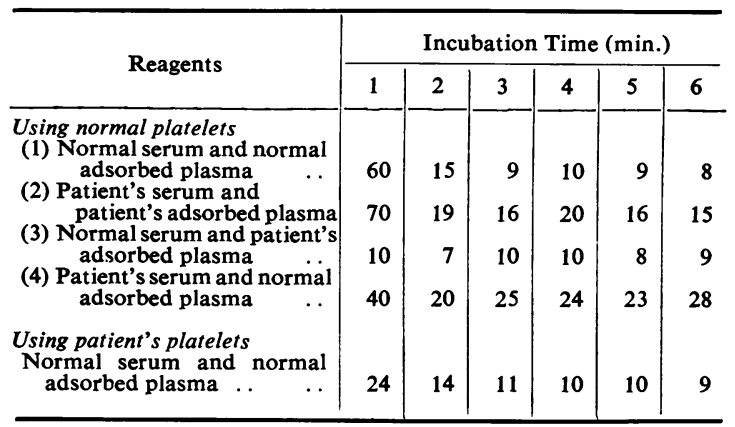

the patient G.P. was similarly affected, and he was treated by transfusing 7 pints of blood. He made a rapid recovery and was sent home on November 9. Two weeks later a repeat thromboplastin generation

\section{TABLE VII}

REPEAT THROMBOPLASTIN ${ }_{4}$ GENERATION TEST ON CASE 2

\begin{tabular}{|c|c|c|c|c|c|c|}
\hline \multirow{2}{*}{ Reagents } & \multicolumn{6}{|c|}{ Incubation Time (min.) } \\
\hline & 1 & 2 & 3 & 4 & 5 & 6 \\
\hline $\begin{array}{l}\text { Using normal platelets } \\
\text { (1) Normal serum and normal } \\
\text { adscrbed plasma } \\
\text { (2) Patient's serum and } \\
\text { patient's adsorbed plasma } \\
\text { (3) Normal serum and patient's } \\
\text { adsorbed plasma } \\
\text { (4) Patient's serum and normal } \\
\text { adsorbed plasma }\end{array}$ & $\begin{array}{r}90 \\
120 \\
90 \\
95\end{array}$ & $\begin{array}{l}60 \\
80 \\
62\end{array}$ & $\begin{array}{l}16 \\
35 \\
20\end{array}$ & 15 & $\begin{array}{l}27 \\
15\end{array}$ & 14 \\
\hline $\begin{array}{l}\text { Using patient's } p \text { ateiets } \\
\text { Normal serum and normal } \\
\text { adsorbed plasma }\end{array}$ & 20 & 15 & 14 & 13 & 12 & 12 \\
\hline
\end{tabular}

test clearly confirmed that he was a case of Christmas disease (Table VII). A barium meal as an out-patient showed a duodenal ulcer; he was placed on an ulcer regime and up to date is well.

\section{REFERENCES}

Biggs, R., and Douglas, A. S. (1953). J. clin. Path., 6, 23. Hicks, N. D., and Pitney, W. R. (1957). Brit. J. Haemat., 3, 227. 